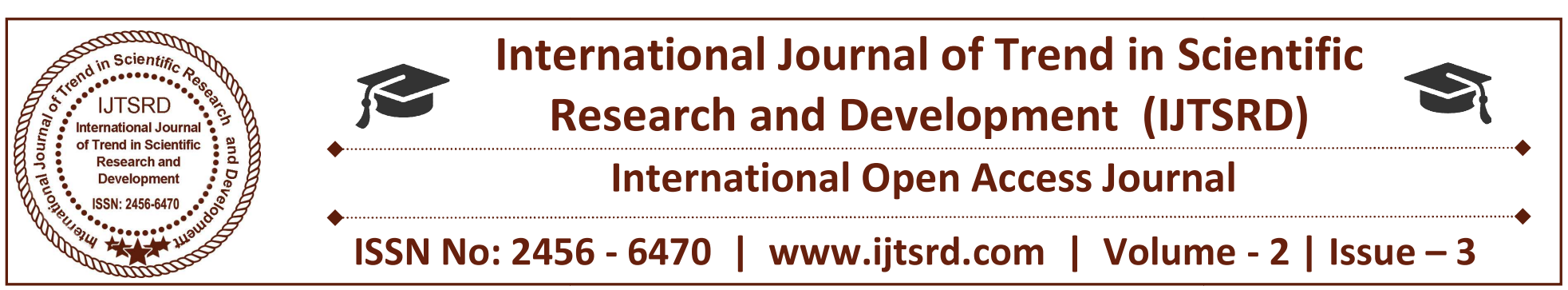

\title{
Utilization of Melon and Snail Shell Waste Mixtures in the Carburization of Mild Steel
}

\author{
Adzor, S. Abella * \\ Department of Industrial \\ Metallurgy and Foundry \\ Engineering, Metallurgical \\ Training Institute PMB 1555, \\ Onitsha
}

\author{
Ihom, P. Aondona \\ Department of Mechanical \\ Engineering, University of Uyo, \\ Uyo-Nigeria
}

\author{
Edibo, $\mathbf{S}$. \\ Department of Metallurgical \\ Engineering Technology, Delta \\ State Polytechnic, Ugwashi-uku
}

\section{ABSTRACT}

As long as industrial and agricultural activities go on, wastes will continue to be generated. In view of this, wastes recycling/or conversion to other reusable materials that can be utilize by another industrial setup is fast receiving worldwide attention. In this research work, the assessment of the suitability of melon and snail shell wastes mixtures in enhancing the surface hardness of mild steel via the pack carburization method has been investigated. The carburization process was carried out at the temperatures of $900^{\circ} \mathrm{C}, 920^{\circ} \mathrm{C}$ and $940^{\circ} \mathrm{C}$ for the soaking times of $15,30,45$ and 60 minutes respectively, and then quenched in water to harden. Thereafter, they were tempered at $250^{\circ} \mathrm{C}$ for 1 hour to relieve the residual stresses introduced into the steel specimens as a result of quenching. Standard method was adopted to determine the surface hardness of the carburized and un-carburized test specimens. Microstructure examination was also performed using standard metallographic techniques to observe the microstructures formed. The results of the study showed increase in the surface hardness of all the carburized steel specimens in the different carburizing media. The steel specimens carburized with $80 \%$ snail shell wastes plus $20 \%$ melon shell wastes mixture had higher hardness values than those carburized with $100 \%$ snail shell wastes only. The maximum surface hardness values of $118 \mathrm{VHN}, 128 \mathrm{VHN}$ and $129 \mathrm{VHN}$ were obtained at the carburizing temperatures of $900^{\circ} \mathrm{C}, 920^{\circ} \mathrm{C}$ and $940^{\circ} \mathrm{C}$ respectively, for the soaking time of 60 minutes with the specimens carburized with snail and melon shell wastes mix. It was observed that the process variables (temperature and soaking time) significantly impacted on the quantity of carbon absorbed at the steel surface as depicted by the surface hardness values. The results of the research work have established the viability of melon and snail shell wastes mixture as an alternative source of carburizers in enhancing the surface hardness of mild steel.

Keywords: Carburization, Surface hardness, Mild steel, Melon shells, Snail shells

\section{INTRODUCTION}

The selection of materials for any given application demands that such materials should possess the requisite mechanical properties to enable it withstand the stresses it is likely to encounter in the proposed service condition. This is very key and should not be compromise as long as safety and proper functioning of engineering facility is concern, and also to avoid premature failure of the facility in service. For instance, components like gears, bearings, cams, crank shaft, rock drilling bits, etc., are expected to have unique balance of properties, where the outer surface is expected to be hard and the inner core to be tough in order to withstand wear and inhibit cracks propagation, respectively [1] [2] [3] [4] [5]. Materials for these applications cannot be produced from medium carbon steels because it is through-hardened and brittle, as such unsuitable. Therefore, by locally 
enriching the surfaces of low carbon steels, followed by quenching in water, a hardened surface and tough inner core can be obtained [6] [7].

Carburization is a heat treatment technique through which certain desirable mechanical properties can be imparted into a metallic material to enable it function properly in the proposed service condition. There are several carburization methods that have been utilized to achieve a hardened surface with a tough inner core. The effectiveness of each method is based on the potential of the diffusing species in the carburizing material and furnace temperature [8]. The carburizing materials that are most often used to achieve this purpose are agricultural wastes, animal wastes or hydrocarbon compound while the energizing materials are usually inorganic chemicals. The most commonly used of these materials are barium carbonate, sodium carbonate and calcium carbonate [3][9]. The high cost of these materials has necessitated the search for alternative carburizing materials that are cheap, readily available and abundant. Results of the proximate analysis carried out by Abdulrazak et al., [10] showed that melon shells contain $17.02 \%$ carbohydrate. Ademolu et al., [11] in their study revealed that snail shells contain high amount of carbohydrate in the range of 83.53 $92.76 \mathrm{~g} / 100 \mathrm{~g}$ depending on the species. The relatively high amount of carbohydrates presence in this waste materials have made them good sources of carbonaceous materials that could be utilize to achieve improved surface hardness of mild steel for use in stringent service condition requiring higher surface hardness. Research carried out by Ihom, et al., [9], Adzor, et al.,[12], Olanike, et al.,[13] on the utilization of some waste materials generated from household, industrial and agricultural activities in the carburization of mild steel have shown that the waste generated from these sources have significantly enhanced the surface hardness of mild steel. Therefore, to properly harness what nature has endowed us with, it is paramount that we begin to take advantage of the numerous waste materials that are generated in our various communities for conversion into new products that could be used by another industry. This will in turn create jobs for the teeming youth, and also help solve environmental problems arising from waste disposal.

Waste is defined as anything un-used or not used to full capacity or excess of what is required or garbage, rubbish or trash. [14] [15] [16]. There are wide varieties of waste that are generated from one industry and community to another as a result of industrial and agricultural activities. Waste cannot be eliminated totally from the environment as long as consistent industrial and agricultural activities go on. Therefore, waste should be recycled or simply converted to other products usable by another industrial set- up as a source of raw materials.

Available researches have shown that extensive work has been carried out on different agricultural wastes and marine materials to establish their suitability as carburizing materials for the surface hardness improvement of mild steel but it is realized that there are numerous other waste materials especially of agricultural products whose viability as alternative source of carburizing material in the carburization of mild steel for improved surface hardness are yet to be adequately explored. The continued search for waste materials with high carbon potential for utilization as carburizing materials in enhancing the surface hardness of mild steel will not only reduce the existing high cost of carburizing mild steel using the highly priced conventional energizers along with existing carbonaceous materials, but also solve waste pollution problem.

Ihom, et al.,[9] investigated the used of egg shell wastes as an enhancer in the carburization of mild steel Adzor et al.,[12] investigated the suitability of periwinkle shells as carburizing material for the surface hardness improvement of low carbon steel. Olanike, et al.,[13], studied the effect of carburizing temperature and time on the mechanical properties of AISI/SAE 1020 Steel using carbonized palm kernel shell. The results obtained by these researchers have proven that some solid wastes has promising carbon potential for enhancing the surface hardness of mild steel.

This research work is aimed at ascertaining the efficacy of utilizing two carbon bearing materials that are considered waste (melon and snail shell) in the carburization of mild steel. The concern here is as a result of the rising cost of the conventional energizers that are widely used by industrialist to raise the carbon potential of many carburizing materials for the surface hardness improvement of mild steel. The base approach consists of correlation of the microstructure with the mechanical property (hardness) and measure of the surface hardness of the carburized steels to establish the carburizing success Report [17] show that melon seeds are grown in large quantities in different part of Nigeria. The seeds are used in the 
preparation of soup among different communities in Nigeria. Report [18] posited that land snails are used as food by humans in various cultures worldwide. In Nigeria, land snails are edible delicacy in the southern and eastern part of Nigeria. However, after the consumption of the melon seeds and the meat of the land snails, their shells are discarded as wastes, thereby creating major issue of environmental pollution. The shell of the snail contains calcium carbonate just like eggshell. It is as a result of this, that the authors have devoted special effort in investigating the possibility of utilizing melon and snail shell wastes mixture as carbonaceous materials in the carburization of mild steel, thereby adding value to these waste materials and at the same time solving solid wastes disposal problem.

\section{Materials and Method}

\subsection{Materials and Equipment}

The materials and equipment utilized for the study were; mild steel, melon shell wastes, snail shell wastes, BS sieve ( 75 microns), steel boxes, muffle furnace, optical microscope, weighing balance, dynamic hardness tester (VHN), water, fireclay, tong, bench vice and hack saw.

\subsection{Method}

The commercial grade of the mild steel used in the study was sourced from the central store of the Metallurgical Training Institute, Onitsha. The chemical composition of the mild steel as-received is shown in Table 1. Figures 1 and 2 represent the photographs of the melon and snail shell wastes. They were sourced locally in Ikpayongo, Gwer East local government of Benue State, Nigeria. The snail shell and the melon shell wastes after cleaning them, they were packed separately in metal boxes and then calcined in a muffle furnace at $500^{\circ} \mathrm{C}$ and $550^{\circ} \mathrm{C}$ respectively, to carbonized them and thereafter grinded and sieved through BS sieve (75 microns). A total of 24 test specimens prepared according to standard specification as per ASTM standard were used for the study. The carburization operation was performed in two stages. In the first stage, 12 test specimens packed separately in metal boxes and embedded in $100 \%$ powdered snail shell wastes only. In the second stage, 12 test specimens were also packed separately in metal boxes containing mixtures of $80 \%$ snail shell wastes and $20 \%$ melon shell wastes. Each of the metal boxes were sealed with fireclay made into paste with water and allowed to dry under the sun before placing each box in turn into the heating chamber of the muffle furnace where they were heated to the temperature of $900^{\circ} \mathrm{C}, 920^{\circ} \mathrm{C}$ and $940^{\circ} \mathrm{C}$ and soaked for $15,30,45$ and 60 minutes respectively. After the carburization, they test specimens were removed from the metal boxes and then quenched in water to harden, thereafter, they were tempered for $250^{\circ} \mathrm{C}$ for 1 hour to relieve the residual stresses introduced into the carburized specimens as a result of quenching.

For effective examination of the internal structures of the carburized steel specimens, standard metallographic techniques were adopted. They specimens were placed on a metallurgical microscope which was adjusted to focus the specimens and the microstructures were photographed, using a magnification of $\mathrm{x} 400$. The hardness values were taken at three different spots on each of the specimen and the average value calculated.

Table 1: Chemical composition of the mild steel plate as- received

\begin{tabular}{|l|l|}
\hline Elements & \% Composition \\
\hline $\mathbf{C}$ & 0.158 \\
\hline Si & 0.219 \\
\hline $\mathbf{M n}$ & 0.493 \\
\hline $\mathbf{P}$ & 0.025 \\
\hline $\mathbf{S}$ & 0.006 \\
\hline $\mathbf{C r}$ & 0.087 \\
\hline $\mathbf{N i}$ & 0.011 \\
\hline $\mathbf{M o}$ & 0.002 \\
\hline $\mathbf{A l}$ & 0.030 \\
\hline $\mathbf{C u}$ & 0.051 \\
\hline $\mathbf{C o}$ & 0.003 \\
\hline $\mathbf{T i}$ & 0.001 \\
\hline $\mathbf{N b}$ & 0.003 \\
\hline $\mathbf{V}$ & 0.002 \\
\hline $\mathbf{W}$ & 0.033 \\
\hline $\mathbf{P b}$ & 0.003 \\
\hline $\mathbf{B}$ & 0.001 \\
\hline $\mathbf{S n}$ & 0.003 \\
\hline $\mathbf{Z n}$ & 0.002 \\
\hline $\mathbf{A s}$ & 0.005 \\
\hline $\mathbf{B i}$ & 0.002 \\
\hline $\mathbf{C a}$ & 0.001 \\
\hline $\mathbf{C e}$ & 0.003 \\
\hline $\mathbf{Z r}$ & 0.002 \\
\hline $\mathbf{L a}$ & 0.002 \\
\hline Fe & 98.9 \\
\hline & \\
\hline
\end{tabular}




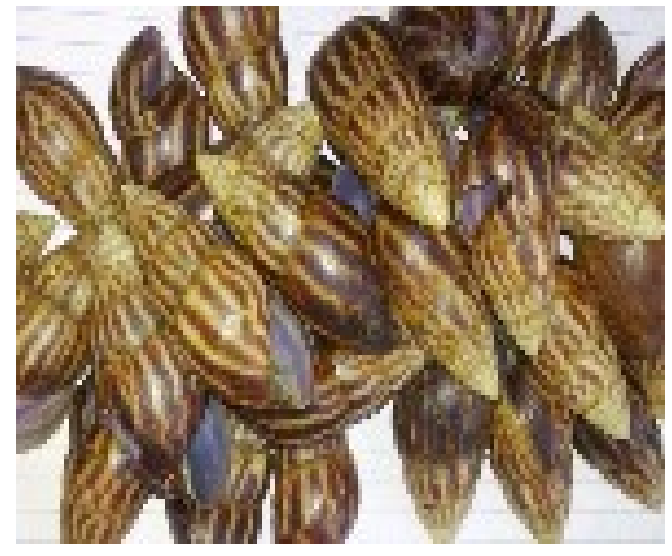

(a)

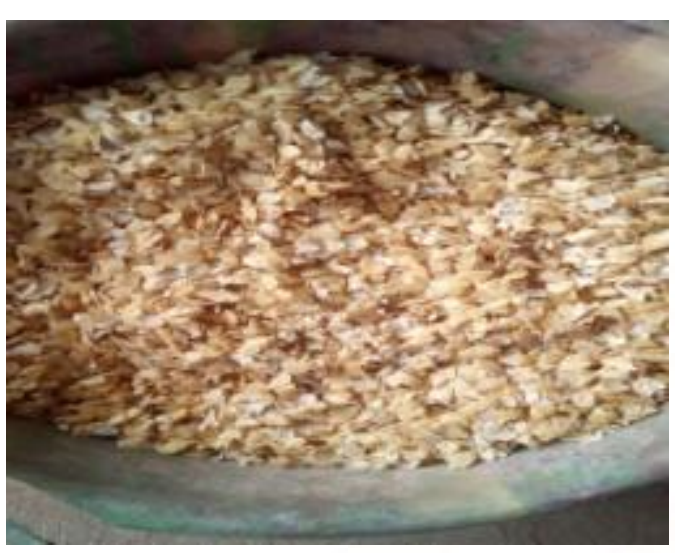

(b)

Figure 1: (a) Photograph of the snail shell wastes and (b) Photograph of the melon shell wastes

\section{Results and Discussion}

The results obtained from the study are shown in Table 2. Figure 3 to 4 show the variation of the surface hardness with the process variables (carburizing temperature and soaking time). The micrographs of the un-carburized test specimen and some of the carburized steel specimens are shown in Figures 5to 8. Table 2 shows the effect of carburizing temperature and soaking time on the surface hardness of the carburized mild steel. It is clearly evident in Table 2 that as the carburizing temperature and soaking time was increased from 900 to $940^{\circ} \mathrm{C}$ at the time intervals of $15,30,45$ and 60 minutes, there was a progressive increase in the surface hardness of all the carburized steel specimens. However, the steel specimens carburized with $80 \%$ snail shell wastes plus $20 \%$ melon shell wastes had higher surface hardness values than those carburized with $100 \%$ snail shell wastes only. This implies that the melon and snail shell wastes mixtures enhances the carbon potential of the carburizing medium which resulted in the higher surface hardness obtained. The melon waste provides carbon while the calcium carbonate in the snail shell gets decomposed at high temperature to play the role of energizer leading to higher carburizing potential [9]. The variation in the surface hardness of the carburized steel specimens is expected since the enrichment of the surface layer of the steel with carbon increases exponentially with temperature and the case depth increases with time although not in direct proportion [3][9][19][20]. Also, the higher the amount of carbon absorbed into the steel, the higher the hardness of the martensite formed. Therefore, the amount of carbon absorbed into the steel at the different carburization temperatures affected the amount, proportion and morphology of the martensite formed during quenching. This is in consonance with reports [12] [21] [22]. 
Table 2: Mechanical Property of Carburized Mild Steels

\begin{tabular}{|c|c|c|c|}
\hline $\begin{array}{l}\text { Sample } \\
\text { ID }\end{array}$ & $\begin{array}{l}\text { Premix } \\
\text { Composition }\end{array}$ & $\begin{array}{l}\text { Soaking } \\
\text { Time (hrs) }\end{array}$ & $\begin{array}{l}\text { Hardness } \\
\text { VHN }\end{array}$ \\
\hline \multicolumn{2}{|c|}{ Control } & & 89 \\
\hline A1 & $100 \%$ Snail shell & 15 & 91 \\
\hline $\mathrm{A} 2$ & $100 \%$ Snail shell & 30 & 93 \\
\hline A3 & $100 \%$ Snail shell & 45 & 97 \\
\hline A4 & $100 \%$ Snail shell & 60 & 101 \\
\hline B1 & $80 \%$ Snail shell $+20 \%$ Melon shell & 15 & 93 \\
\hline B2 & $80 \%$ Snail shell $+20 \%$ Melon shell & 30 & 95 \\
\hline B3 & $80 \%$ Snail shell $+20 \%$ Melon shell & 45 & 103 \\
\hline B4 & $80 \%$ Snail shell $+20 \%$ Melon shell & 60 & 118 \\
\hline $\mathrm{C} 1$ & $100 \%$ Snail shell & 15 & 96 \\
\hline $\mathrm{C} 2$ & $100 \%$ Snail shell & 30 & 99 \\
\hline $\mathrm{C} 3$ & $100 \%$ Snail shell & 45 & 117 \\
\hline $\mathrm{C} 4$ & $100 \%$ Snail shell & & 120 \\
\hline D1 & $80 \%$ Snail Shell $+20 \%$ Melon shell & 15 & 101 \\
\hline D2 & $80 \%$ Snail Shell $+20 \%$ Melon shell 12920 OU & 30 & 103 \\
\hline D3 & $80 \%$ Snail Shell $+20 \%$ Melon shell $\quad 920$ & 45 & 121 \\
\hline D4 & $\begin{array}{r}80 \% \text { Snail Shell }+20 \% \text { Melon shell } 920 \\
\text { Research a }\end{array}$ & 60 & 128 \\
\hline E1 & $100 \%$ Snail Shell & 15 & 98 \\
\hline E2 & $100 \%$ Snail Shell & 30 & 101 \\
\hline E3 & $100 \%$ Snail Shell & 45 & 120 \\
\hline E4 & 100\% Snail Shell $\quad$ ISSN: 2 & & 124 \\
\hline F1 & $80 \%$ Snail Shell $+20 \%$ Melon shell & 15 & 104 \\
\hline $\mathrm{F} 2$ & $80 \%$ Snail Shell $+20 \%$ Melon shell 940 & 30 & 110 \\
\hline F3 & $80 \%$ Snail Shell $+20 \%$ Melon shell $\quad 940$ & 45 & 127 \\
\hline F4 & $80 \%$ Snail Shell $+20 \%$ Melon shell & 60 & 129 \\
\hline
\end{tabular}

Figure 3: (a) and (b) show the variation of surface hardness with carburizing temperature of the steel specimens carburized with snail and melon shell wastes mix, and snail shell wastes only, respectively. The Figures indicates that as the carburizing temperature was increased from $900^{\circ} \mathrm{C}-940^{\circ} \mathrm{C}$, there was a steady increase in the surface hardness values of all the carburized steel specimens. However, it was observed that the steel specimens carburized with the snail and melon shell wastes mix, exhibited higher surface hardness increase than those carburized with snail shell wastes only. The higher surface hardness exhibited by the steel specimens carburized with the melon and snail shell wastes mixtures indicates that the melon and snail shell wastes enhances the carbon potential of the carburizing medium, which in turn resulted in the higher surface hardness obtained. Report [7] stated that the maximum surface hardness that could be attain by any carburized steel depends on the carbon potential of the carburizing material and the quantity of carbon that is absorb at the steel surface. This quantity increases with increase in temperature. The variation in the surface hardness with carburizing temperature implies that temperature has a strong influence on the rate of diffusion. According to report [19] the higher the temperature of heating, the higher the solubility of carbon in austenite iron, and the higher the surface hardness that will be attain by the steel when it is quench in water. This is in agreement with reports [23][24]. 


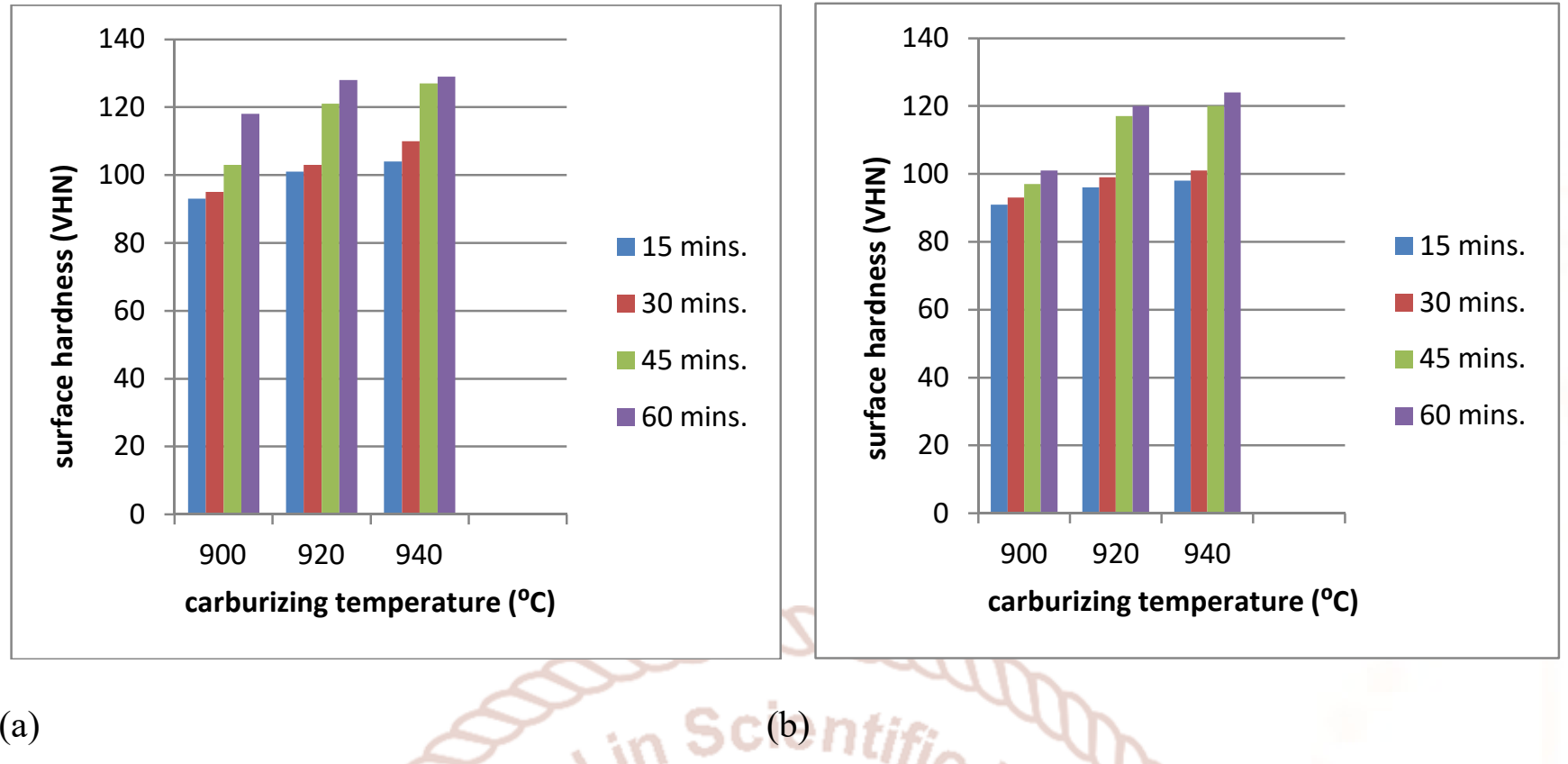

Figure 3: (a) Variation of surface hardness with carburizing temperature of steel carburized with snail and melon shell wastes mix and (b) Variation of surface hardness with carburizing temperature of steel carburized with snail shell wastes only.

Figure 4: (a) and (b) shows the variation of surface hardness with soaking time of the steel specimens carburized with melon and snail shell wastes mix, and with snail shell wastes only, respectively. The Figures clearly show that at any given carburizing temperature as the soaking time was increased from 15-60 minutes, the surface hardness of the carburized steel specimens' increases. The variation in the surface hardness with soaking time is expected since report [24] stated that at any given temperature, the quantity of carbon absorbed by any carburized steel increases with time. Report [25] stated that, the amount of carbon that could be picked up by steel is a function of time and the available carbon potential in the furnace atmosphere. Therefore, the high carbon potential arising from the snail and melon shell wastes mix is largely responsible for the highly improved surface hardness obtained by the steel specimens carburized in the snail and melon shell wastes mix carburizing medium compared to those carburized in the snail shell wastes carburizing medium.

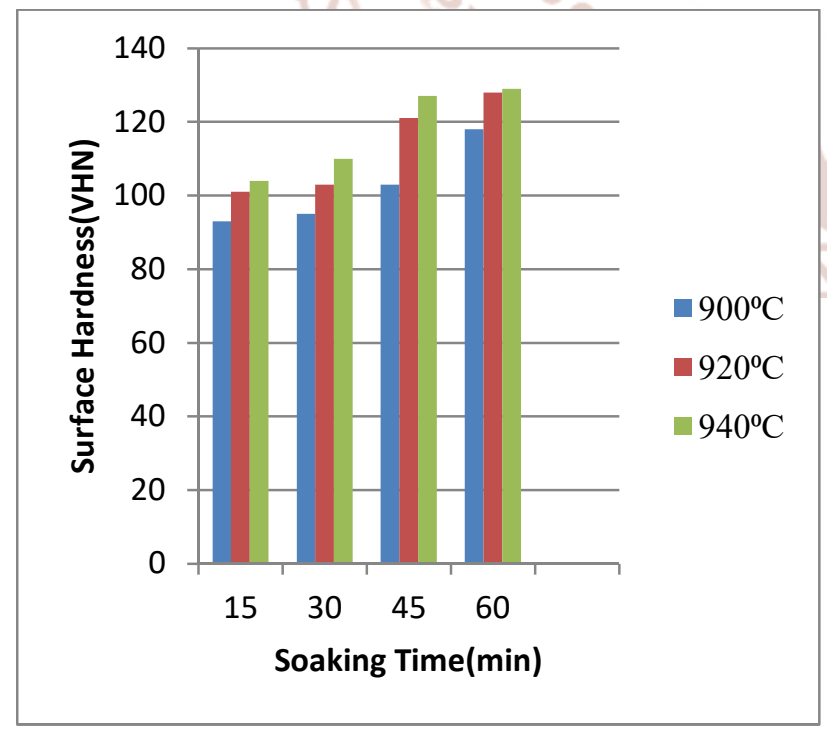

(a)

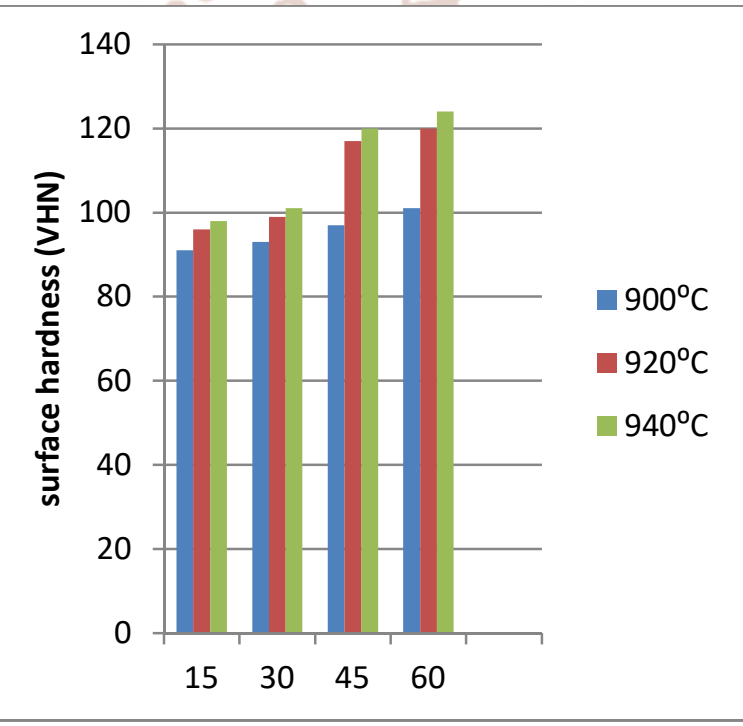

(b) 
Figure 4: (a) Variation of surface hardness with soaking time of steel carburized with snail and melon shell wastes mix and (b) Variation of surface hardness with soaking time of steel carburized with snail shell wastes only.

Figure 5 revealed the micrograph of the un-carburized (untreated) as-received. The micrograph indicates the presence of pearlite in ferrite matrix. The coarse grain size of the microstructure clearly accounts for the lower surface hardness of the un-carburized steel specimens as compared to the carburized steel specimens.

Figures 6-8 show the micrographs of the steel specimens carburized at $900^{\circ} \mathrm{C}, 920^{\circ} \mathrm{Cand} 940^{\circ} \mathrm{C}$, and soaked for 60 minutes. They micrographs consist of tempered martensite and dispersed carbide in ferrite matrix. However, the micrographs of the steel specimens carburized with $80 \%$ snail shell wastes plus $20 \%$ melon shell wastes revealed the presence of more proportion of tempered martensite with varying degree of dispersed carbide along the ferrite grain boundary as compared to the micrographs of the steel specimens carburized with $100 \%$ snail shell wastes only. Hence, the higher surface hardness values obtained by the specimens carburized with snail and melon shell mix.

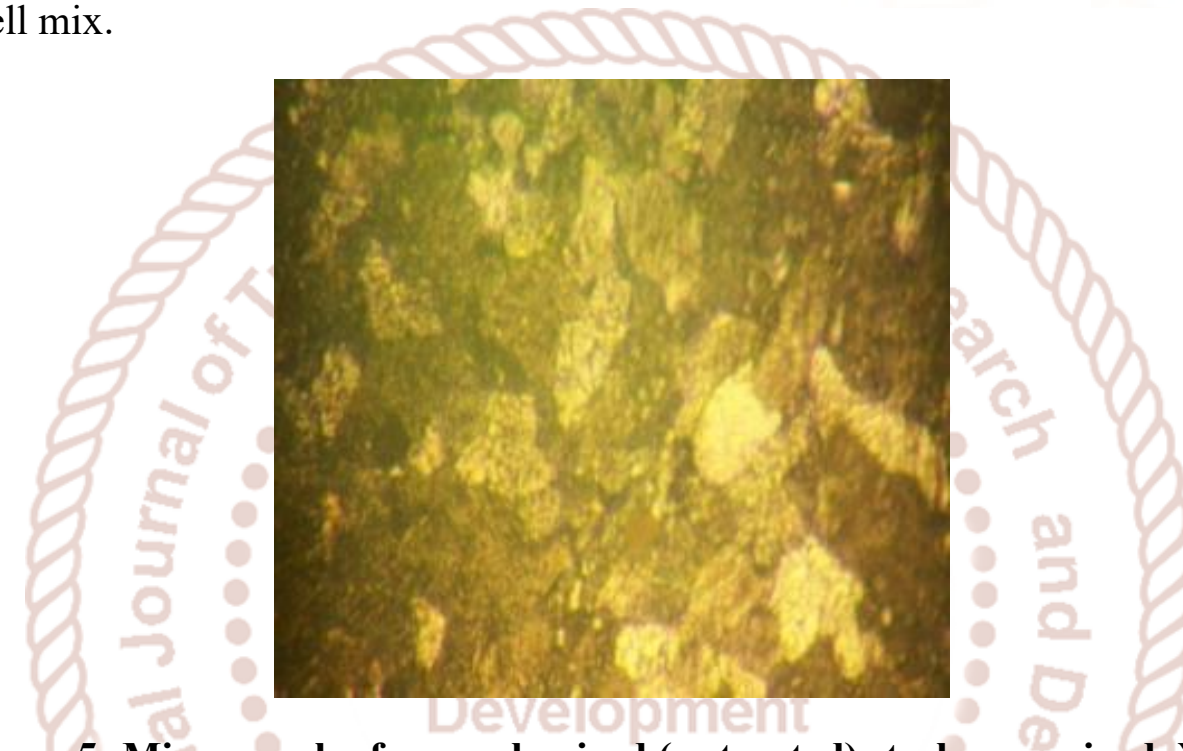

Figure 5: Micrograph of un-carburized (untreated) steel as-received. X400

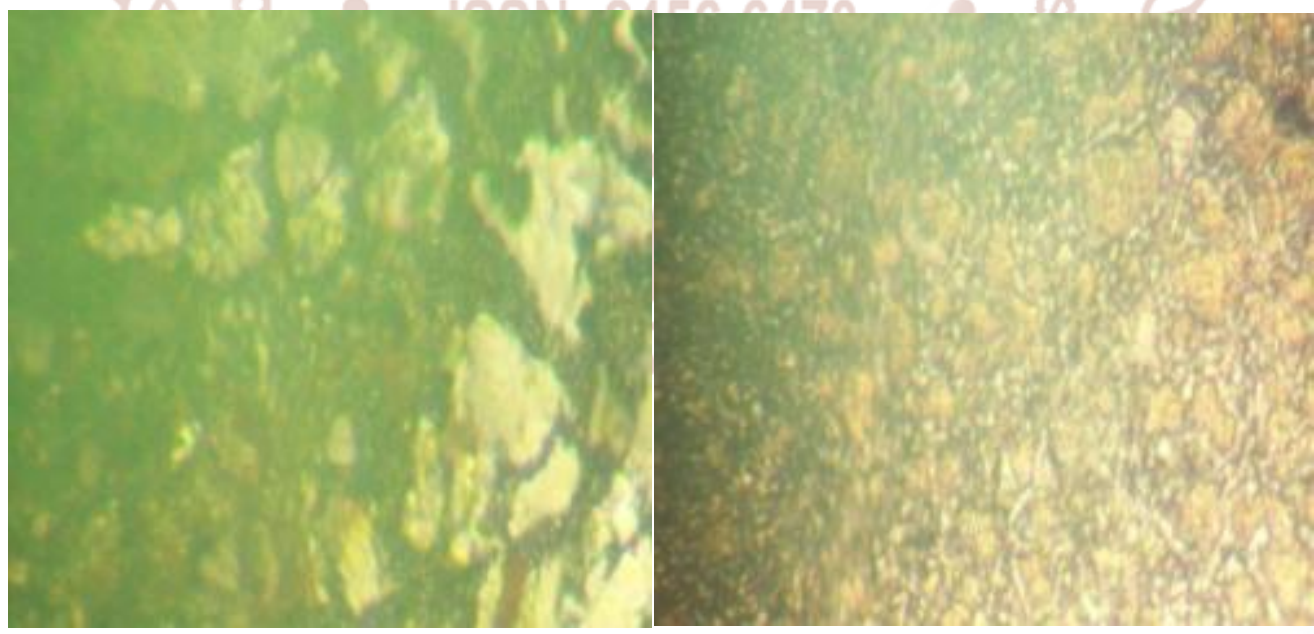

(a) $\mathrm{X400}$

(b) $\mathrm{X400}$

Figure 6: (a) Micrograph of steel carburized with 100\% snail shell wastes onlyand (b) Micrograph of steel carburized with snail and melon shell wastes mix. (Carburized at $900^{\circ} \mathrm{C}$, soaked for 60 minutes) 


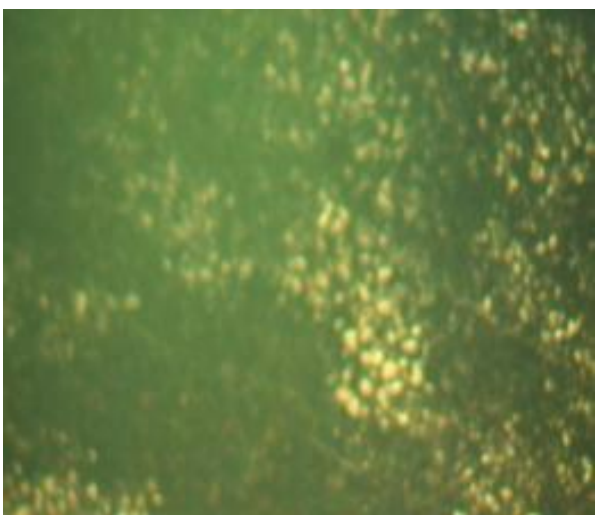

(a) $\mathrm{X} 400$

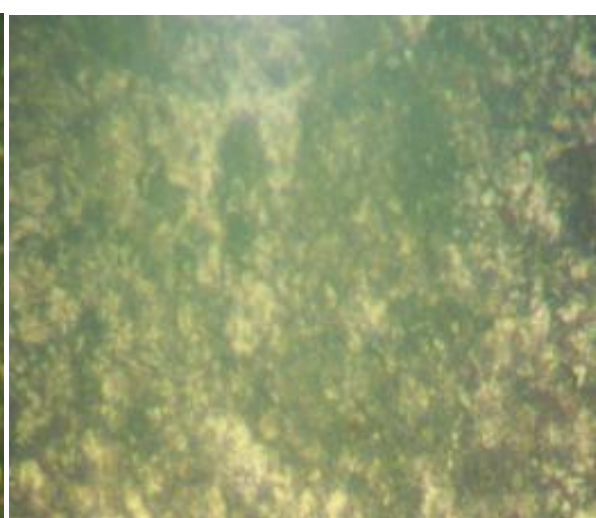

(b) $\mathrm{X} 400$

Figure 7: Micrograph of steel carburized using 100\% snail shell wastes onlyand (b) Micrograph of steel carburized with snail and melon shell wastes mix. (Carburized at $920^{\circ} \mathrm{C}$, soaked for 60 minutes)

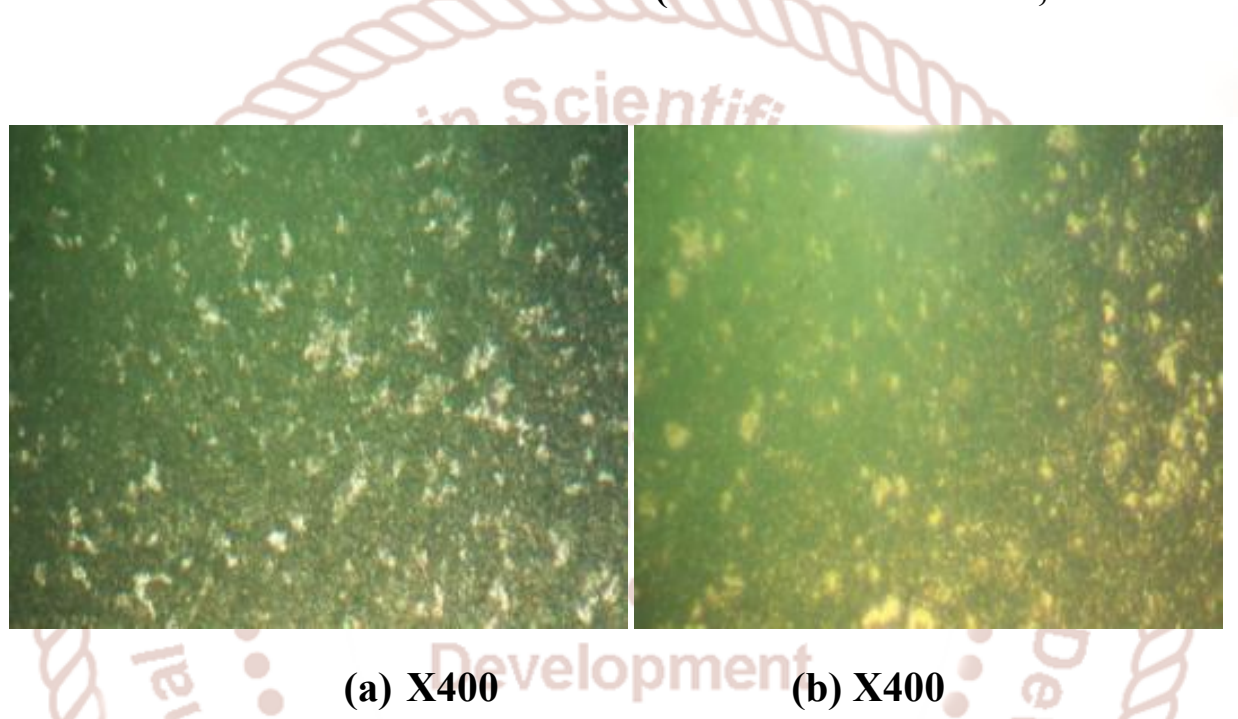

Figure 8: (a) Micrograph of steel carburized using 100\% snail shell wastes only and (b) Micrograph of steel carburized with snail and melon shell wastes mix (Carburized at $940^{\circ} \mathrm{C}$, soaked for 60 minutes)

\section{Conclusion}

On the basis of the overall results of the study, the following conclusions have been drawn:

1. The study observed that the surface hardness of all the carburized steel specimens' increases steadily as the carburizing temperature and soaking time was increased. This implies that temperature and soaking time had strong influences on the rate of absorption and diffusion of carbon into the steel surface.

2. It was also observed that the steel specimens carburized with snail and melon shell wastes mixtures exhibited higher surface hardness values than those carburized with snail shell wastes only. This suggests that the melon and snail shell wastes mixtures raised the carbon potential of the carburizing medium.
3. The study has open a new door for the utilization of melon and snail shell wastes mixture as a cheap, readily available and good alternative source of carbonaceous materials to be used alone, without the addition of the highly priced conventional energizers for the surface hardness improvement of mild steel for use in stringent service condition requiring higher surface hardness.

\section{References}

1) Mallick, A. (2011). Principles of Physical Metallurgy, published by Viva Books private limited, New Delhi. Pp.324

2) Smith, W. F., Hashemi, J. and Prakash (2008). Materials science and engineering $\left(4^{\text {th }} \quad\right.$ ed.).

Published in India for McGraw-Hill, Inc., New York. Pp184. 
International Journal of Trend in Scientific Research and Development (IJTSRD) ISSN: 2456-6470

3) Khanna, O. P. (2008). Material Science and Metallurgy. Published by Ish Kapur for DahanpatRai publications (p) Ltd. New Delhi. pp. 44-3.

4) Singh, V. (2011), Physical Metallurgy, published by A. K. Jain for Standard publishers Distributors, New Delhi. Pp.571

5) Sanjib, K. J (2009), Heat Treatment of Low Carbon Steel, Undergraduate Degree

Project. Department Mechanical Engineering, National Institute of Technology. Pp. 1314. Retrieved August 12, 2016 from ethesis.nitrkl.ac.in/1138/1/

6) George, F. V. and Gabriel, M. L. (2009). Microstructural Characterization of 37.

Carburized Steels. Heat Treating Process. Pp.

7) Degarmo, E. P., Black, J.T. and Kohser, R. A. (1997) Materials and Processes in manufacturing ( $8^{\text {th }}$ ed.) published by Prentice-Hall, India. Pp. 132. Retrieved December 16, from https://www.amazon.com

8) Nor, A. N. (2007). Effect of Carburization on Mechanical Properties of Low Carbon Steel. Undergraduate Degree Project, Department of Mechanical Engineering, FakultiKejuruteraanMekanikal, Universiti Teknikal, Malaysia, Melaka. Pp.5-6. Retrieved from eprints.utem.edu.my/18449

9) Ihom, A. P., Nyior, G. B., Nor, I. J. and Ogbodo, N. J. (2013). Investigation of Egg Shell Waste as an Enhancer in the Carburization of Mild Steel. American Journal Materials Science and Engineering, 1(2), pp. 29-33

10) Abdulrazak, S., Otie, D. and Oniwapele, Y. A. (2014) Proximate Analysis and AntiNutritional Factors of Groundnut and Melon Husk. Online Journal of Animal and Feed Research, vol. 4, issue 2, pp. 27.

11) Ademolu, K. O., Akintola, M. Y., Olalonye, A. O. and Adelabu, B. A. (2015) Tradional Utilization and Biochemical Composition of Six Mollusc Shells in Nigeria. Rev. boil.

Trop, vol. 63, no. 2 San Jose

12) Adzor, S. A., Nwoke, V. U. and Akaluzia, R. O. (2016). Investigation of the suitability of Periwinkle Shell as Carburizing Material for the Surface Hardness Improvement of Low Carbon Steel. European Journal of Material

Sciences, vol. 3, No. 2, pp. 13-23

13) Olanike, M. O., Samuel, R. O., Iyiola, O. O. and Fatai, O. A. (2015). Effect of Carburizing temperature and time on the Mechanical properties of AISI/SAE 1020 Steel using carbonized palm kernel. Leonardo EIJ Pract. Technol. 2015(27), pp. 41-56

14) Definition of waste. Retrieved February 7, 2017 from www.wastedictionary.com

15) What is waste? Retrieved February 7, 2017 from www.fullcycle.co.za/index.php

16) Zero waste. Retrieved 7, February 2017 from www.zerowasteamerica.org

17) Ogbe, A. O., Alu, S. E., Moses, A. and Obeka, A. D. (2013). Utilization of melon shell husk with mushroom as enzyme supplement: Effect on performance of boiler chicken. International Journal of Research Studies in Biosciences (IJRSB) vol. 1, issue 2, pp. 2

18) Land snails.Retrieved February 10, from https://en.wikipedia.org/wiki/land_snail

19) Singh, V. (2007). Heat Treatment of Metals. Published by A. K. Jain for Standard Publishers Distributors, New Delhi. pp. 276, 334, 335 and 336.

20) Singh, V. (2011). Physical Metallurgy. Published by A.K. Jain for Standard Publishers

Distributor, New Delhi. pp. 570-571.

21) Nwoke, V. U., Nnuka, E. E., Odo, J. U. and Obiorah, S. M. O. (2014). Effect of process variables on the mechanical properties of surface hardened mild steel quenched in different Media. Journal of Scientific and Technological Researh, Vol. 3, Issue 4. Pp.390-393.

22) Raghavan,V. (1989). Physical Metallurgy: Principles and Practice. Published by PrenticeHall of India, New Delhi. pp.135.

23) Jaykant, G. (2009). Mechanical and wear properties of carburized mild steel samples Master of Engineering Thesis, National Institute of Technology, Rourkela. Pp.36-42. Retrieved June, 1, 2015, from www.docstoc.com.

24) Yang, C. E., Chiu, L. H. and Wu, J. K. (1995). Effect of carburization and hydrogenation on the impact toughness of AISI4118 steel. Surface and Coating Technology, 73, pp. 1822.

25) Rajput, R. K. (2010). Material Science and Engineering. Published by S. K. Kataria and Sons, New Delhi. Pp.336-337. 